\title{
Rekomendasi Pekerjaan Dari Portal Bursa Lowongan Kerja Memanfaatkan Fitur Cosine Similarity dan Simple Additive Weighting
}

\author{
Rahma Ningsih*1, Yufiz Azhar², Yuda Munarko ${ }^{3}$ \\ 1,2,3 Teknik Informatika/Universitas Muhammadiyah Malang \\ rahmaningsih.1326@gmail.com¹,yufiz.az@gmail.com²
}

\begin{abstract}
Abstrak
Pencarian informasi melalui portal bursa lowongan kerja memanfaatkan mesin pencari (search engine) yang terdapat pada situs layanan. Hasil pencarian oleh sistem didasarkan pada kesamaan query inputan, kemudian hasilnya ditampilkan dengan model sortir yang terbatas pada hierarkis abjad atau angka. Sehingga diperlukan waktu lagi untuk memilah informasi yang dibutuhkan, karena hasil informasi yang ditampilkan sistem juga diantaranya merupakan informasi yang kurang sesuai. Sebab itu diperlukanlah adanya pengembangan model perankingan terhadap rekomendasi informasi dari hasil pencarian tersebut. Metode cosine similarity dalam pengimplementasiannya menghasilkan data sesuai dengan query yang diinputkan user, serta ditambah dengan menerapkan metode simple additive weighting sebagai metode perankingan terhadap data retrive hasil cosine similarity. Sistem memiliki fitur unggulan, yaitu model perankingan yang bertingkat sehingga user dapat menentukan sendiri aturan perankingan dengan menentukan kriteria mana yang cendrung dominan.
\end{abstract}

Kata Kunci: Cosine Similarity, Simple Additive Weighting, Sistem rekomendasi, Perankingan

\begin{abstract}
Seeking information on job vacancy portals are use search engines tools that already contained on the service site. The search results by the system are based on the similarity of input queries, then the results are displayed with a sort model limited to hierarchical alphabets or numbers. So, it takes a longer time to sort out the required information, because the results of information displayed by the system also contained some irrelevant information. Therefore, is being necessary to develop other ranked models to recommend some information from the search results. Cosine similarity method in the implementation of the data accordance to query that inputted by user, and then applying a method of simple additive weighting as a ranked method for the retrive data of cosine similarity results. The system has excellent features too, namely the multilevel ranking model so users can define their own ranking rules by determining which criteria tends is dominant.
\end{abstract}

Keywords: Cosine Similarity, Simple Additive Weighting, Recommendation system, Ranked

\section{Pendahuluan}

Pin et al (2001) dalam penelitiannya menyebutkan bahwa pada berbagai negara di Eropa, dari 167 organisasi perusahaan ditemukan sedikitnya sebanyak $83 \%$ organisasi perusahaan tersebut telah memiliki website perusahaan [1]. Eksistensi sebuah website bagi perusahaan menunjukkan suatu konsekuensi perusahaan terhadap pengguna media digital dalam memberikan kemudahan untuk proses pengaksesan suatu informasi dari perusahaan tersebut. Salah satu bentuk kemudahan tersebut adalah informasi rekrutmen. Boxall dan Purcell (2003) menyebutkan bahwa regenerasi anggota orga-nisasi melalui proses rekrutmen merupakan bagian penting bagi suatu organisasi. Selain tujuan kolektif massa, proses rekrutmen juga secara strategis bertujuan untuk memperoleh calon-calon kandidat yang berkualitas [2].

Informasi rekrutmen juga disediakan oleh portal bursa lowongan kerja. Portal bursa lowongan kerja merupakan penghimpun informasi lowongan dari berbagai perusahaan yang mengiklan ke situs tersebut. Pencarian informasi pada portal bursa lowongan kerja memanfaatkan mesin pencari (search engine) untuk mengolah dan menghasilkan informasi sesuai query yang diinputkan user. Hasil pengurutan informasi yang dihasilkan situs layanan tersebut masih terbatas 
pada hirarkis abjad dan tanggal atau kemiripan query semata. Sehingga diperlukan waktu lagi untuk memilah-milah informasi yang sesuai.

Dalam penelitian sebelumnya, Cosine similarity diterapkan untuk menilai kemiripan pada pencarian terjemahan ayat-ayat al-qur'an dan hadist shahih oleh Yeni Suswatiningsih (2012). Hasil yang diperoleh dari pengujian pada 25 koresponden terhadap pencarian keyword memperoleh presentase kesesuaian hasil sebesar $26,32 \%$ [3]. Guna meningkatkan presentase kesesuaian hasil, menilai dari aspek kesamaan keyword saja menjadi kurang relevan untuk meberikan rekomendasi lowongan kerja.

Henry Wibowo (2010), dalam penelitiannya yang berjudul aplikasi uji Sensitifitas untuk model multi atribute decision making menggunakan metode simpel additive weighting dan TOPSIS, menjelaskan bahwa metode simple additive weighting merupakan metode yang cocok untuk proses pengambilan keputusan karena dapat menentukan nilai bobot untuk setiap kriteria. Selain itu, metode tersebut juga memiliki fitur berupa hasil ranking yang diperoleh dari proses seleksi terhadap alternatif dari sejumlah alternatif terlibat [4]. Dengan penggabungan metode tersebut [3][4], penelitian ini lebih tepat guna untuk memaksimalkan hasil pencarian terhadap informasi lowongan kerja. Tujuan penelitan ini adalah mengimplementasikan metode cosine similarity dan simple additive weighting untuk memperoleh rekomendasi lowongan pekerjaan yang lebih relevan dan teranking.

\section{Metode Penelitian}

Sistem rekomendasi berbasis web dalam penelitian ini memiliki dokumen informasi lowongan kerja yang diperoleh secara kolektif dari objek penelitian. Konten umum pada sistem berupa model form inputan untuk pengguna, dilengkapi fitur pembobotan untuk masing-masing kriteria. Adapun kebutuhan data pada setiap dokumen dalam penelitian ini diantaranya berupa posisi pekerjaan, kontak instansi, baik berupa nomor telepon atau situs resmi perusahaan, lokasi perusahaan, jumlah gaji, informasi kriteria perekrutan meliputi kualifikasi pendidikan, waktu kerja dan pengalaman kerja.

Penelitian ini mengkombinasi proses dengan memanfaatkan metode cosine similarity dan simple additive weighting. Penambahan metode simple additive weighting dipertimbangkan sebagai hal yang perlu dikarenakan metode cosine similarity dilakukan untuk memproses inputan yang berupa deskripsi kualifikasi oleh user. Guna memperoleh rekomendasi lowongan kerja secara teranking diperlukan model pembobotan terhadap kriteria yang terlibat secara bertingkat, maka diterapkan metode simple additive weighting untuk memproses tahap perankingan dari data retrive lowongan kerja hasil proses cosine similarity. Penggambaran alur proses tersebut secara keseluruhan dapat dilihat pada Gambar 1 berikut.

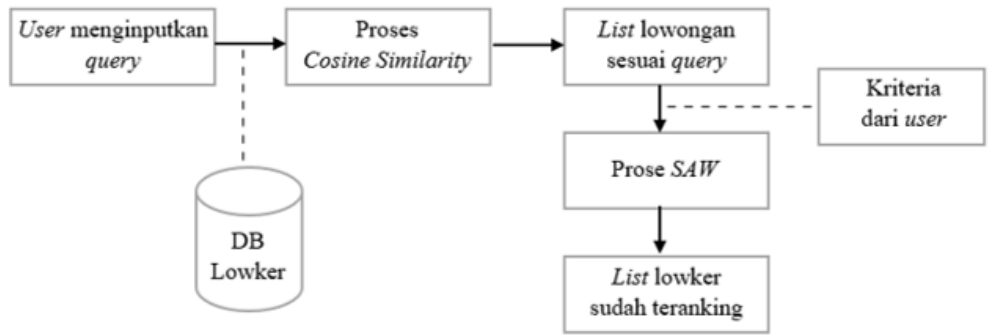

Gambar 1. Kerangka Kerja Sistem Rekomendasi dan Perankingan dengan Cosine Similarity dan Simple Additive Weighting

\section{Ekstraksi Informasi}

Pengumpulan data untuk sistem dalam penelitian ini, diperoleh melalui teknik ekstraksi informasi. Ekstraksi informasi merupakan proses mengubah informasi tidak terstruktur menjadi sebuah informasi yang terstruktur. Contoh dari informasi yang tidak terstruktur adalah informasi yang ada pada halaman-halaman website. Artikel-artikel yang dimuat pada suatu website sebagian besar berupa informasi yang tidak terstruktur, karena biasanya terdiri dari muatan berupa informasi utama atau konten utama, iklan, navigasi, dan informasi tambahan lainnya [5]. Banyaknya akumulasi dari informasi tersebut berakibat pada sulitnya untuk mendapatkan inti informasi utama, sulit menemukan nilai dan pengetahuan yang relevan dalam bentuk informasi terstruktur, seperti bentuk basis data.

REPOSITOR, Vol. 2, No. 5, Mei 2020: 601-610 
Web scraping adalah teknik yang biasa digunakan untuk menuai informasi dari halaman website. Teknik scraping web sering kali dimanfaatkan untuk menghimpun data penting berupa teks [6]. Guna mengotomatisasi proses scraping salah satunya adalah dengan memanfaatkan perangkat lunak yang menyediakan antar muka untuk merekam informasi pada website. Pada penelitian ini, aplikasi yang digunakan untuk proses scraping adalah Web Harvy.

\section{Processing Dokumen}

Umumnya data yang diperoleh dari database suatu perusahaan maupun eksperimen, memiliki isian-isian yang tidak sempurna seperti mengandung kata yang hilang, data yang tidak valid, atau juga hanya sekedar salah ketik. Selain itu juga ada atribut data yang tidak relevan dan baiknya dibuang karena keberadaannya bisa mengurangi mutu atau akurasi dari value data nantinya. Tahapan preprocessing diperuntukkan guna menyelaraskan informasi menjadi data teks yang dapat dibaca dan diolah oleh sistem untuk proses retrive dan perankingan. Adapun tahapan preprocessing yang diterapkan dalam penilitian ini, diantaranya adalah editing, case folding, tokenizing, dan menghapus stop word.

\subsection{Editing}

Tahapan pertama pada preprocessing adalah editing, yakni proses untuk mengubah beberapa kata berbahasa inggris ke dalam bahasa indonesia serta mengubah beberapa kata disingkat menjadi kata aslinya. Proses ini dilakukan manual terhadap data setelah memperoleh dokumen data hasil ektraksi yang berformat *.csv.

\subsection{Case Folding}

Case folding merupakan tahapan mengubah semua huruf menjadi huruf kecil pada dokumen yang merupakan data sistem. Hanya data berupa huruf saja yang diproses dengan case folding, sedangkan karakter selain huruf maka akan dihilangkan [7]. Karakter selain huruf tersebut diantaranya ( . ), ( , ), ( - ), (/), (<), ( > ) dan (").

\subsection{Tokenizing}

Tokenizing adalah tahapan mengurai string yang diinputkan pengguna menjadi perkata. Guna memudahkan pembacaan data inputan, penggunaaan spasi diberlakukan untuk memisahkan antar kata satu dengan lainnya [7].

\subsection{Stop Word Removal}

Stopword removal adalah tahap filtering kata-kata berdasarkan hasil tokenizing. Dalam proses ini, peneliti memiliki stoplist atau daftar kata-kata yang tidak deskriptif atau dianggap tidak penting [7]. Jika pada prosesnya kata-kata tersebut muncul didalam sistem, maka kata tersebut akan dihilangkan. Contoh stopword diantaranya adalah "yang", "dan", "di", "dari" dan lain-lain. Berikut Gambar 2 yang menunjukkan alur kerja dari processing dokumen.

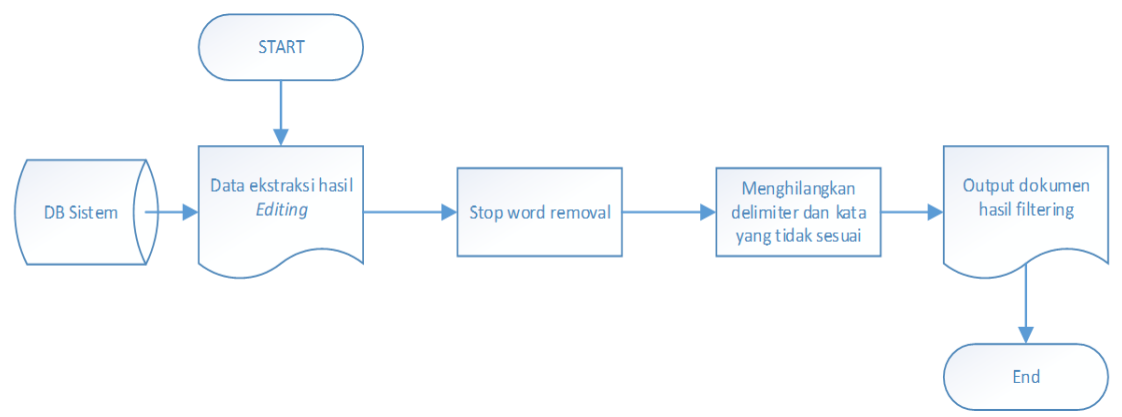

Gambar 2. Flowchart Text Processing Meliputi Case Folding, Tokenizing dan Stopword Removal

3. Analisa Fitur Term Frequency - Inverst Document Frequency (TF-IDF)

Proses TF-IDF dilakukan sebagai tahap pembobotan kata. Nilai $d f$ diperoleh dengan menghitung banyaknya kemunculan kata (term) pada dokumen data. Sedangkan idf didapat sesuai dengan Persamaan 1 [8]. 


$$
i d f=\log (n / d f)
$$

dan untuk menghitung $w$ didapatkan melalui Persamaan 2.

$$
t f \times i d f=t f(d, t) \times i d f(t)
$$

\section{Analisis Metode Cosine Similarity}

Cosine similarity merupakan pengukur tingkat kesamaan yang umum dan banyak digunakan pada proses information retrieval dan merupakan pengukur sudut antar dua vektor dokumen, yaitu $D_{a}$ (titik $\left.(a x, b x)\right)$ dan $D_{b}$ (titik $\left(a y\right.$, by)). Setiap vektor $\left(D_{a}\right.$ dan $\left.D_{b}\right)$ merepresentasikan tiap term dari sebuah dokumen yang kemudian dibandingkan dan membentuk suatu pola segitiga, sehingga diterapkan hukum kosinus dalam menyatakan bahwa Persamaan $3[9]$.

$$
\cos (C)=a^{2}+b^{2}-c^{2} / 2
$$

Dimana Persamaan 4.

$$
a^{2}=a x^{2}+a y^{2}=b x^{2}+b y^{2}
$$

dan Persamaan 5.

$$
c^{2}=(b x-a x)^{2}+(a y-b y)^{2}
$$

Gantikan nilai-nilai tersebut untuk a,b, dan $c$ sehingga didapatkan Persamaan 6.

$$
\cos C=\frac{a_{x} b_{x}+a_{y} b_{y}}{\sqrt{a_{x^{2}}+a_{y^{2}}} \times \sqrt{b_{x^{2}}+b_{y^{2}}}}
$$

Konversi rumus pada Persamaan 7 adalah sebagai berikut:

$$
C(Q, D)=\frac{\Sigma T F \cdot I D F}{\Sigma W D, t^{2}}
$$

Dengan $\Sigma T F . I D F$ merupakan $t \in Q \cap D$ sedangkan $\Sigma W D, t^{2}$ merupakan $t \in D$

\section{Analisis Metode Simple Additive Weighting (SAW)}

Metode simple additive weighting (SAW) merupakan suatu metode yang dapat diterapkan untuk peanjumlahan terbobot. Konsep dasar dari metode SAW sendiri adalah mencari nilai akumulatif berupa bobot terhadap setiap alternatif dari semua atribut yang terlibat didalam sistem.

Melalui proses cosine similarity dihasilkan presentase berupa nilai preferensi dari setiap alternatif yang terlibat yang kemudian disebut data retrive. Pada prose cosine similarity ditunjukkan bahwa setiap dokumen alternatif memiliki nilai berbeda. Hasil tersebut didasarkan pada tingkat similaritas antar dokumen yang dibandingkan. Guna meranking dan menghasilkan rekomendasi diterapkan metode simple additive weighting untuk membobot setiap kriteria yang disediakan sistem sebagai acuan sortir.

Terdapat lima kriteria yang dapat dibobotkan pada sistem, diantaranya judul kerja, lokasi, upah gaji, pendidikan, dan pengalaman. Dari kriteria yang telah ditentukan, kriteria lokasi dan gaji membutuhkan suatu tingkat kepentingan kriteria berdasarkan nilai bobot yang telah ditentukan ke dalam bilangan fuzzy dengan rumus yaitu variabel ke-n/n-1 dan menghasilkan nilai bobot sesuai Tabel 1 dan Tabel 2.

Tabel 1. Range dan Nilai Bobot Tiap Variabel Pada Kriteria Lokasi

\begin{tabular}{c|c} 
Range & Bobot \\
$750 \mathrm{~s} / \mathrm{d}>1000 \mathrm{~km}$ & Variabel ke-0/(4-1)=0 \\
$500 \mathrm{~s} / \mathrm{d} 749 \mathrm{~km}$ & Variabel ke-1/(4-1)=0,33
\end{tabular}

REPOSITOR, Vol. 2, No. 5, Mei 2020: 601-610 


\begin{tabular}{c|l}
$250 \mathrm{~s} / \mathrm{d} 499 \mathrm{~km}$ & Variabel ke-2 / (4-1) $=0,67$ \\
$0 \mathrm{~s} / \mathrm{d} 249 \mathrm{~km}$ & Variabel ke-3 / (4-1) $=0,75$
\end{tabular}

Tabel 2. Range dan Nilai Bobot Varibel Pada Kriteria Gaji

\begin{tabular}{c|c}
\hline Range & Bobot \\
\hline Rp 7.200.000 s/d Rp 9.000.000 & Variabel ke-0 / (5-1)=0 \\
Rp 5.4000.000 s/d Rp 7.199.000 & Variabel ke-1/ (5-1)=0,25 \\
Rp 3.600.000 s/d Rp 5.399.000 & Variabel ke-2/(5-1)=0,5 \\
Rp 1.800.000 s/d Rp 3.599.000 & Variabel ke-3/ (5-1)=0,75 \\
Rp 0 s/d Rp 1.799.000 & Variabel ke-4 / (5-1)=1 \\
\hline
\end{tabular}

Pada metode penelitian ini, user dapat mengatur kriteria yang ada pada sistem untuk dipilih sebagai acuan proses ranking. Karena bersifat pembobotan bertingkat, Tabel 3 berikut nilai bobot yang ditetapkan berdasarkan posisi peletakan kriteria.

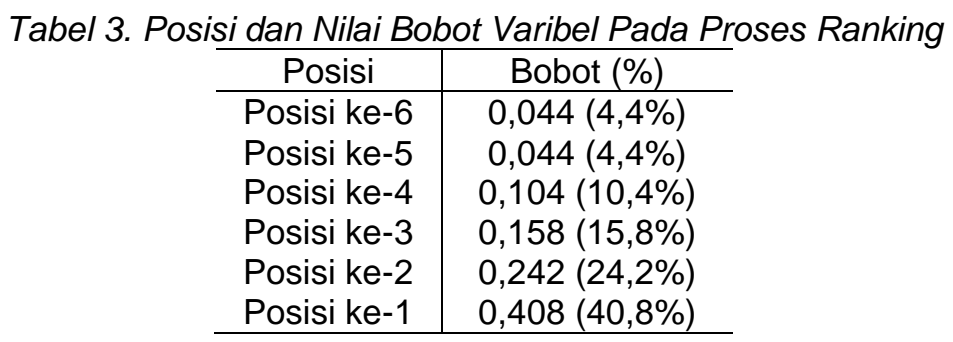

Pada proses normalisasi terdapat dua atribut terlibat yaitu benefit dan cost. Untuk menghitung kriteria dengan atribut benefit perlu diketahui nilai maksimal dari kriteria judul kerja, lokasi, dan upah gaji dalam matriks keputusan. Sedangkan atribut cost memerlukan nilai minimun dari kriteria pengalaman dan Pendidikan. metode SAW membutuhkan proses normalisasi matriks keputusan ke dalam skala yang kemudian akan dibandingkan ke semua bobot alternatif yang terlibat. Diterapkan sebuah Persamaan 8 [10].

$$
r_{i j}= \begin{cases}\frac{X_{i j}}{M a x X_{i j}} & \text { Jika } j \text { adalah atribut benefit } \\ \frac{\text { Min } X_{i j}}{X_{i j}} & \text { Jika j adalah atribut cost }\end{cases}
$$

\section{Hasil Penelitian dan Pembahasan \\ 3.1 Implementasi Ekstraksi Website}

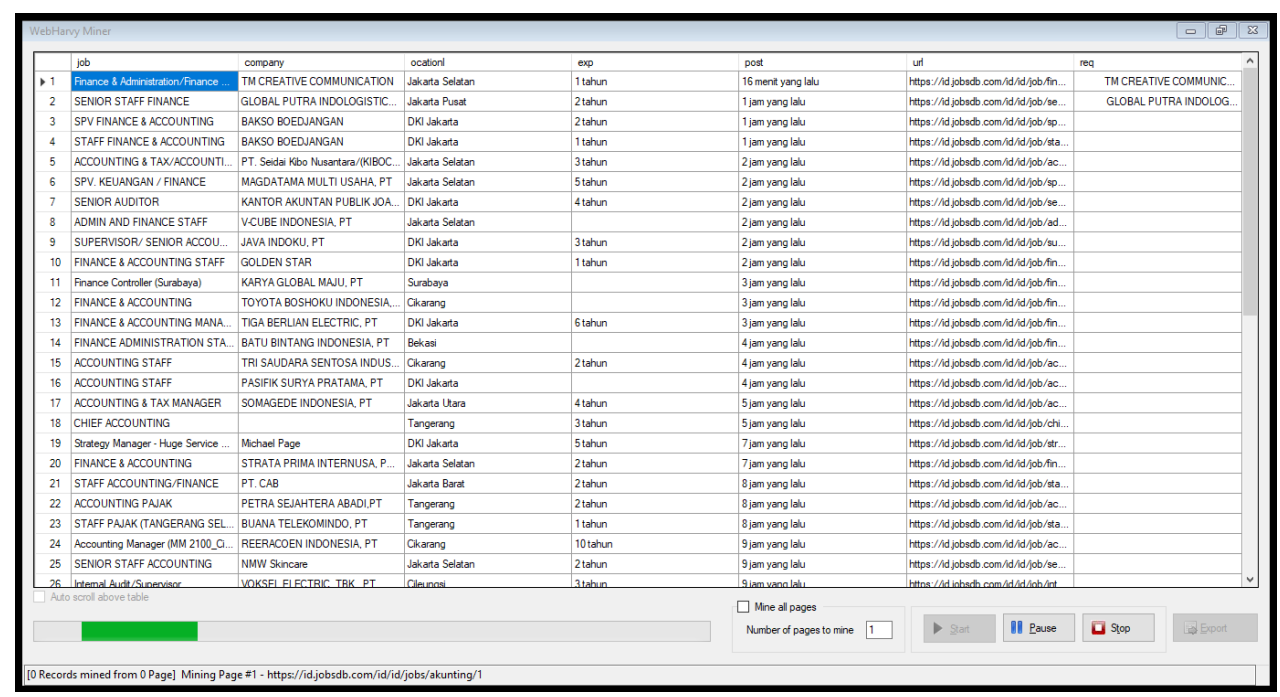

Gambar 3. Aplikasi Melakukan Proses Ekstraksi Data Ke Dalam Kolom 
Aplikasi yang digunakan untuk mengekstraksi website adalah aplikasi Web Harvy. Aplikasi membutuhkan koneksi ke internet untuk dapat mengekstrak data-data dari situs yang dituju dalam mengumpulkan informasi.

Pada Gambar 3 diatas menujukkan proses ekstraksi data oleh aplikasi. Setelah proses mengekstrak selesai, pengguna dapat menyimpan data menjadi dua macam format yaitu *.csv atau langsung diimport ke dalam database.

Pada penelitian ini, data hasil ekstraksi disimpan kedalam format *.csv. File tersebut kemudian melalui tahapan editing. Editing merupakan tahap memecah data hasil ekstraksi, karena data yang diekstrak masih berantakan diperlukan proses merapikan informasi tersebut

\subsection{Implementasi Tampilan Antar Muka}

Pada Gambar 4, ditampilkan beranda (home) dari antar muka system saat user melakukan akses. Pada halaman ini, pengguna dapat mengisikan nama pekerjaan ke dalam form inputan bebas, serta dapat menambahkan bidang keahlian dan jenis waktu kerja yang dicari. Sistem juga menampilkan kolom kriteria lainnya dan pengguna dapat memilih kriteria memanfaatkan drop down option. Apabila kolom belum terisi, maka sistem menampilkan warning seperti pada Gambar 5.

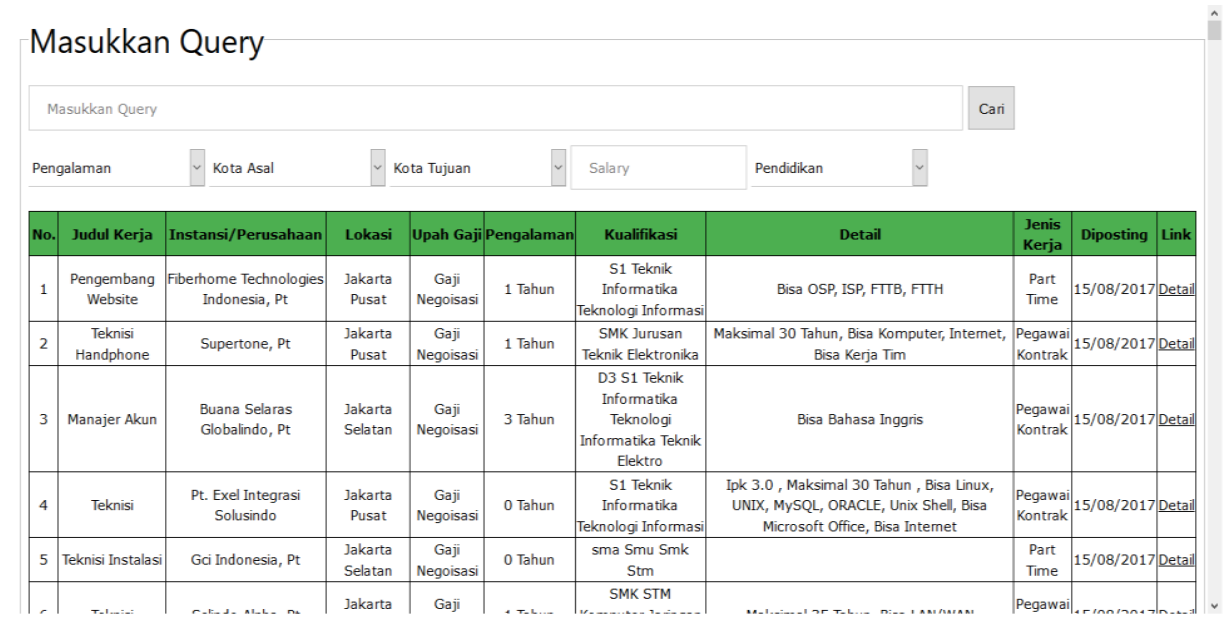

Gambar 4. Splash Screen Tampilan Halaman Utama

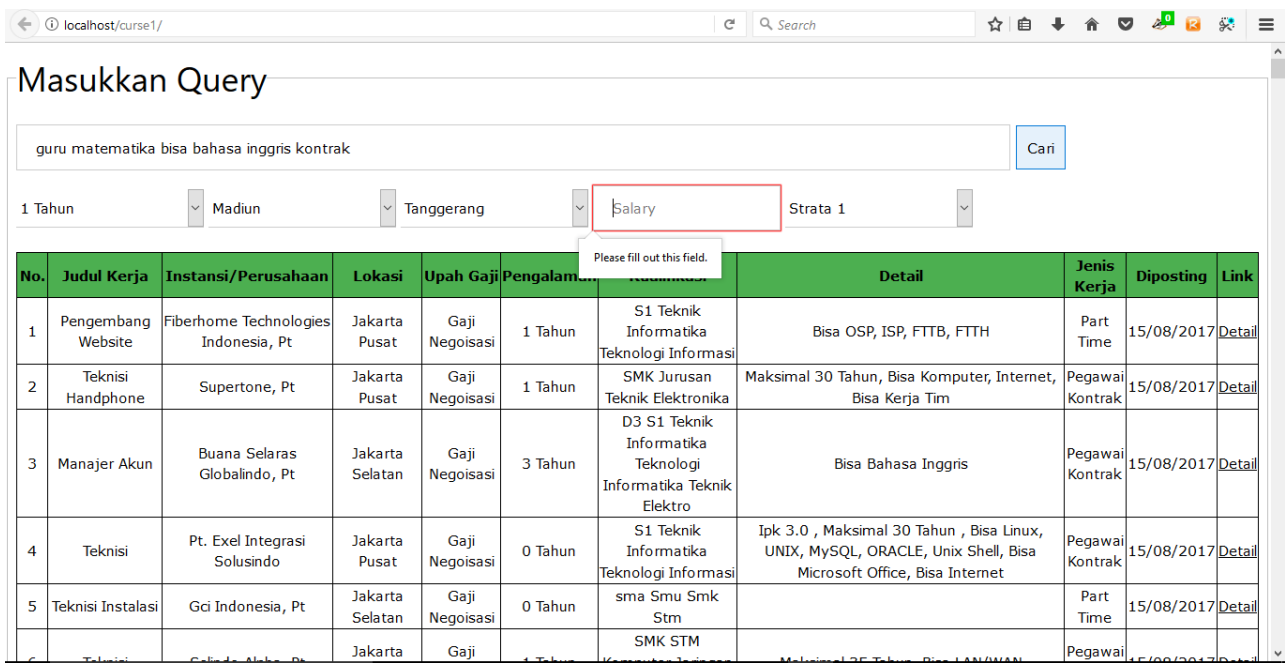

Gambar 5. Notifikasi Warning Apabila Ada Kolom yang Belum Terisi

\subsection{Implementasi Cosine Similarity}

Proses ini dilakukan untuk meretrive data lowongan pekerjaan berdasarkan kesamaan antara query dengan keseluruhan data di dalam database. Lebih tepatnya, proses cosine similarity diberlakukan untuk memudahkan sistem membaca query pada form inputan bebas.

REPOSITOR, Vol. 2, No. 5, Mei 2020: 601-610 
Setiap data retrive kemudian memiliki value yang digunakan sebagai penentu dokumen lowongan kerja yang terekomendasikan.

Gambar 6 dibawah ini menampilkan lowongan kerja yang sudah teretrive bedasarkan kesamaan term melalui metode cosine similarity. Pada halaman ini, user diminta mengatur tingkatan kriteria untuk kemudian diranking dengan metode simple additive weighting. Masingmasing posisi sudah memiliki nilai presentase dan lebih memudahkan user untuk tinggal mengatur peletakan kriteria.

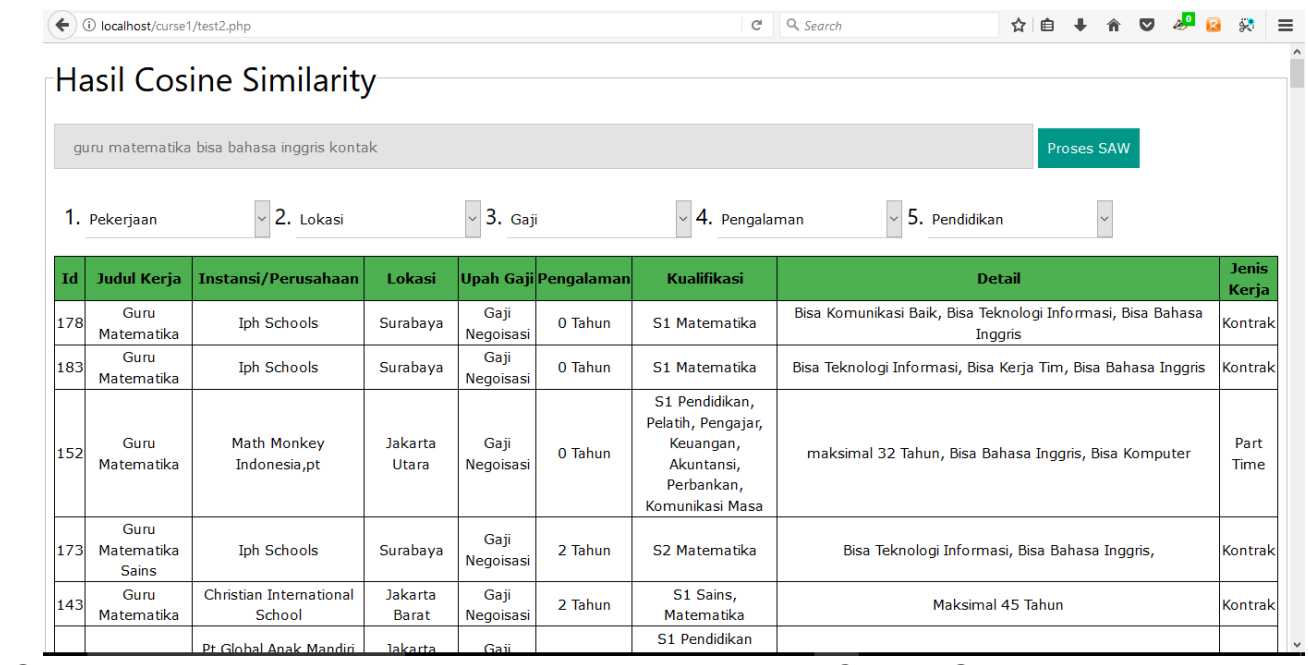

Gambar 6. Tampilan Halaman Redirect Berupa Hasil Cosine Similarity dan Kolom Fitur Pembobotan

\subsection{Implementasi Simple Additive Weighting (SAW)}

Proses ini merupakan tahap final dari serangkaian proses perankingan. Keseluruhan variabel yang diproses pada tahap sebelumnya telah memiliki value, kemudian dinormalisasi hingga menghasilkan nilai SAW. Tampilan halaman hasil ditunjukkan oleh Gambar 7 dibawah ini.

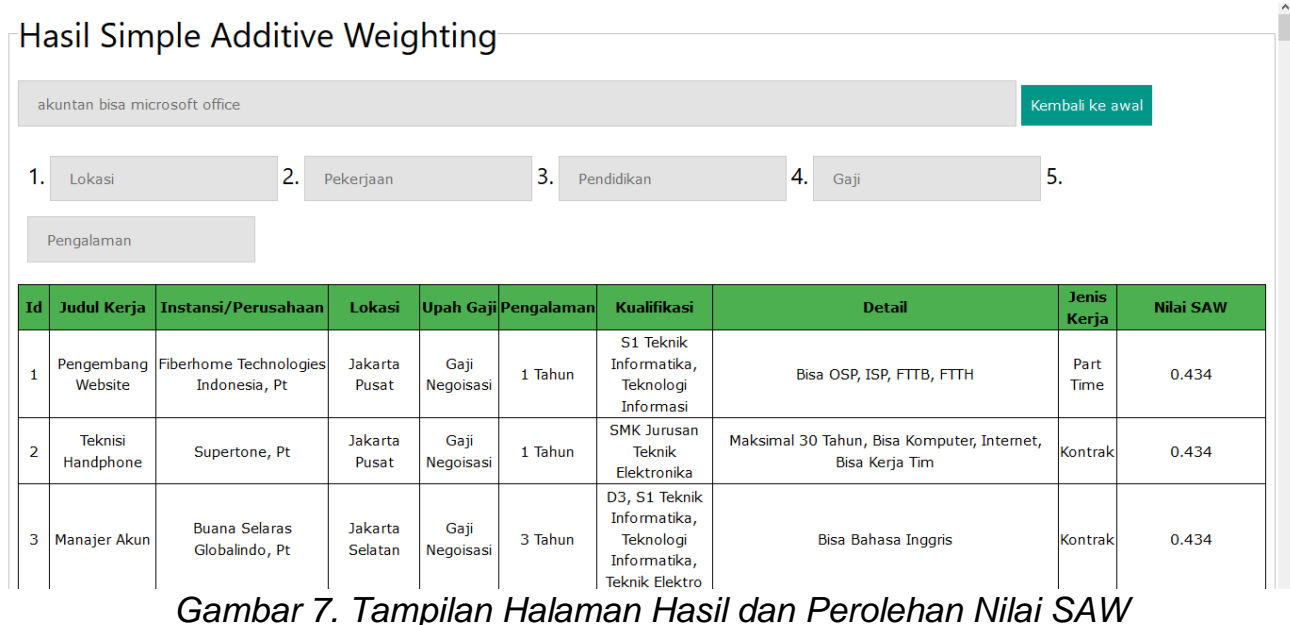

\subsection{Hasil Pengujian}

Pada pengujian kuisoner berdasarkan evaluasi user, dilibatkan sebanyak sepuluh koresponden, dengan masing-masing koresponden memasukkan query sebanyak dua kali ke dalam sistem. Kuisioner melakukan uji perankingan dan jumlah hasil evaluasi yang diinginkan user dengan menentukan kesesuaian hasil rekomendasi sistem terhadap 20 data thereshold. Data thereshold merupakan 20 data dengan nilai rekomendasi tertingi pada proses akhir. Gambar 8 menunjukkan statistik data dari rekapan hasil evaluasi oleh user. Adapun notasi 1 (angka) merupakan dokumen rekomendasi yang dinilai sesuai, sedangkan 0 merupakan dokumen rekomendasi yang dinilai kurang sesuai. 


\begin{tabular}{|c|l|c|c|c|c|c|c|c|c|c|c|c|c|c|c|c|c|c|c|c|c|c|c|}
\hline No Uji & Koresponden & D1 & D2 & D3 & D4 & D5 & D6 & D7 & D8 & D9 & D10 & D11 & D12 & D13 & D14 & D15 & D16 & D17 & D18 & D19 & D20 & Sesuai & Tidak Sesuai \\
\hline 1 & Responden 1 & 0 & 0 & 0 & 1 & 1 & 0 & 1 & 1 & 0 & 0 & 0 & 0 & 0 & 0 & 0 & 0 & 0 & 0 & 0 & 0 & 4 & 16 \\
\hline 2 & & 1 & 0 & 1 & 1 & 1 & 0 & 1 & 0 & 0 & 0 & 0 & 0 & 0 & 0 & 0 & 0 & 0 & 0 & 0 & 0 & 5 & 15 \\
\hline 3 & Responden 2 & 1 & 1 & 0 & 0 & 0 & 0 & 0 & 1 & 1 & 1 & 0 & 1 & 0 & 0 & 0 & 0 & 0 & 0 & 0 & 0 & 6 & 14 \\
\hline 4 & & 0 & 0 & 0 & 0 & 1 & 0 & 0 & 0 & 1 & 0 & 0 & 1 & 0 & 0 & 0 & 0 & 1 & 0 & 0 & 0 & 4 & 16 \\
\hline 5 & Responden 3 & 1 & 1 & 0 & 0 & 0 & 0 & 0 & 0 & 0 & 0 & 0 & 0 & 0 & 0 & 0 & 0 & 0 & 0 & 0 & 0 & 2 & 18 \\
\hline 6 & & 0 & 1 & 1 & 0 & 0 & 0 & 1 & 0 & 1 & 1 & 0 & 0 & 0 & 0 & 1 & 1 & 0 & 0 & 0 & 0 & 7 & 13 \\
\hline 7 & Responden 4 & 0 & 0 & 0 & 0 & 1 & 0 & 0 & 1 & 0 & 0 & 0 & 0 & 0 & 0 & 0 & 0 & 0 & 0 & 0 & 1 & 3 & 17 \\
\hline 8 & & 1 & 1 & 1 & 0 & 0 & 0 & 0 & 0 & 0 & 0 & 0 & 0 & 0 & 0 & 0 & 0 & 0 & 0 & 0 & 0 & 3 & 17 \\
\hline 9 & Responden 5 & 0 & 0 & 1 & 1 & 0 & 0 & 0 & 0 & 0 & 0 & 0 & 0 & 0 & 0 & 0 & 0 & 0 & 0 & 0 & 0 & 2 & 18 \\
\hline 10 & & 1 & 1 & 1 & 1 & 0 & 1 & 1 & 1 & 0 & 0 & 0 & 0 & 1 & 0 & 0 & 1 & 0 & 0 & 1 & 1 & 11 & 9 \\
\hline 11 & Responden 6 & 0 & 0 & 0 & 1 & 1 & 1 & 0 & 0 & 1 & 0 & 0 & 0 & 0 & 0 & 0 & 0 & 0 & 0 & 0 & 0 & 4 & 16 \\
\hline 12 & & 1 & 1 & 1 & 0 & 0 & 0 & 0 & 0 & 0 & 0 & 0 & 0 & 0 & 0 & 0 & 0 & 0 & 0 & 0 & 0 & 3 & 17 \\
\hline 13 & Responden 7 & 1 & 0 & 0 & 0 & 0 & 0 & 0 & 0 & 0 & 0 & 0 & 0 & 0 & 0 & 0 & 0 & 0 & 0 & 0 & 0 & 1 & 19 \\
\hline 14 & & 1 & 1 & 1 & 0 & 1 & 1 & 1 & 0 & 0 & 0 & 0 & 0 & 0 & 0 & 0 & 0 & 0 & 0 & 0 & 0 & 6 & 14 \\
\hline 15 & Responden 8 & 1 & 1 & 1 & 0 & 0 & 0 & 0 & 0 & 0 & 0 & 0 & 0 & 0 & 0 & 0 & 0 & 0 & 0 & 0 & 0 & 3 & 17 \\
\hline 16 & & 1 & 1 & 1 & 1 & 1 & 0 & 0 & 0 & 0 & 0 & 0 & 0 & 0 & 0 & 0 & 0 & 0 & 0 & 0 & 0 & 5 & 15 \\
\hline 17 & Responden 9 & 1 & 1 & 0 & 1 & 1 & 0 & 0 & 0 & 0 & 0 & 0 & 0 & 0 & 0 & 0 & 0 & 0 & 0 & 0 & 0 & 4 & 16 \\
\hline 18 & & 0 & 0 & 0 & 1 & 0 & 0 & 0 & 0 & 0 & 0 & 0 & 1 & 1 & 1 & 0 & 0 & 0 & 0 & 0 & 0 & 4 & 16 \\
\hline 19 & Responden 10 & 0 & 1 & 1 & 1 & 0 & 0 & 0 & 0 & 0 & 0 & 0 & 0 & 0 & 0 & 0 & 0 & 0 & 0 & 0 & 0 & 3 & 17 \\
\hline $\mathbf{2 0}$ & & 1 & 1 & 0 & 0 & 0 & 0 & 0 & 0 & 0 & 0 & 0 & 0 & 0 & 0 & 0 & 0 & 0 & 0 & 0 & 0 & 2 & 18 \\
\hline
\end{tabular}

Gambar 8. Data Rekap Hasil Kesesuaian

Dari hasil kuisioner pada Gambar 8, masing-masing responden melakukan dua kali percobaan terhadap sistem, sehingga secara keseluruhan didapatkan 20 query inputan yang diuji dan dievaluasi oleh respoden. Untuk mengetahui keakuratan nilai presisi dalam menghitung ratarata presentase kesuaian hasil, maka aturan perhitungan dibagi kedalam tiga cara banding, yaitu untuk presisi terhadap lima dokumen (precision @5), presisi terhadap sepuluh dokumen (precision@10) dan presisi terhadap 20 dokumen (precision @20).

Hasil pengujian menunjukkan perolehan nilai rata-rata sebesar $51,59 \%$ terhadap data banding sebanyak lima dokumen yang direkomendasikan. Adapun nilai rata-rata sebesar $34,5 \%$ terhadap data banding sebanyak sepuluh dokumen yang direkomendasikan dan nilai rata-rata sebesar $20,5 \%$ terhadap data banding sebanyak 20 dokumen yang direkomendasikan

\section{Kesimpulan}

Dari hasil uji coba yang dilakukan pada akhir perancangan penelitian ini, dapat dirumuskan beberapa kesimpulan sebagai berikut:

1. Sistem rekomendasi lowongan pekerjaan untuk membantu memberikan rekomendasi informasi lowongan kerja dengan sistem perankingan kriteria secara bertingkat dapat dilakukan dengan mengimplementasikan metode simple additive weighting.

2. Dari hasil pengujian cosine similarity diperoleh data retrive berdasarkan similaritas query inputan. Data retrive dengan nilai tertinggi akan muncul dalam peringkat teratas.

3. Dari hasil uji oleh sepuluh koresponden terhadap thereshold sebanyak 20 dokumen rekomendasi teratas, diperoleh nilai rata-rata sebesar $51,59 \%$ terhadap data banding sebanyak lima dokumen yang direkomendasikan. Adapun nilai rata-rata sebesar $34,5 \%$ terhadap data banding sebanyak sepuluh dokumen yang direkomendasikan dan nilai rata-rata sebesar $20,5 \%$ terhadap data banding sebanyak 20 dokumen yang direkomendasikan.

Adapun saran pengembangan untuk kemajuan sistem di masa mendatang berdasarkan pada penelitian ini, diantaranya adalah sebagai berikut:

1. Sistem dapat mengimplementasikan cara perankingan dengan menggunakan metode multiple attribute decision lainnya.

2. Menyediakan tabel kesamaan keyword judul kerja, dengan tujuan merekomendasikan pekerjaan yang memiliki penyebutan berbeda namun masih pada satu fungsi kerja yang sama.

3. Membuat sistem tagging dengan metode named entity recognition untuk pembacaan lebih baik terhadap inputan pada form bebas.

4. Membuat sistem dapat terintegrasi secara real time dengan objek penelitian sehingga informasi lowongan kerja dapat terus up to date.

\section{Daftar Notasi}

Berikut daftar notasi dari fungsi-fungsi yang dicantumkan dalam jurnal penelitian ini:

d : dokumen

$t \quad$ :kata

tf $\quad$ : banyaknya $t$ yang muncul pada $d$

$n \quad:$ total $d$

REPOSITOR, Vol. 2, No. 5, Mei 2020: 601-610 


\begin{tabular}{ll}
\hline$d f$ & : banyak $d$ yang mengandung $t$ \\
$Q$ & $:$ query inputan user \\
$r_{i j}$ & $:$ nilai rating kinerja ternormalisasi \\
$X_{i j}$ & $:$ nilai atribut dari suatu kriteria \\
$M \operatorname{Mx}_{i j}$ & : nilai terbesar dari suatu kriteria \\
$\operatorname{Min}_{i j}$ & : nilai terkecil dari suatu kriteria
\end{tabular}

\section{Referensi}

[1] T. S. Purnomo, "Rekrutmen Online (E-Recruitment) Sebagai Suatu Inovasi Dalam Perekrutan Perusahaan," vol. 7, no. 3, pp. 54-59, 2013.

[2] Z. Malik, "The Role of E-recruitment Towards Attraction of Workforce: A Case of Telecom Sector Organization.," Abasyn Univ. J. Soc. Sci., vol. 6, no. 1, pp. 104-115, 2013.

[3] Y. Suswatiningsih, "Implementasi Cosine Similarity Untuk Menilai Kemiripan Pada Pencarian Terjemahan Ayat-ayat Al-Qur'an dan Hadist Shahih," Universitas Muhammadiyah Malang, 2012.

[4] Firdaus, "Implementasi Simple Additive Weighting untuk Rekomendasi Pencari Kerja Terbaik Dalam Sistem Informasi Lowongan Kerja," Jurnal Edik Informatika, 2011.

[5] E. Susanti, "Ekstraksi Informasi Konten Web Menggunakan Pendekatan Berbasis Ontologi," vol. 7, no. Februari 2015. : https://www.researchgate.net/publication/295906067, pp. 128136, 2016.

[6] Z. Zaira, "Implementasi Ekstraksi Web Untuk Hadits Yang Diterjemahkan Dalam Bahasa Indonesia," 2011.

[7] D. Juang, "Analisis Spam Dengan Menggunakan Naïve Bayes," vol. 3, no. 1998, pp. 51-57, 2016.

[8] D. Susanto, A. Basuki, and P. Duanda, "Deteksi Plagiat Dokumen Tugas Daring Laporan Praktikum Mata Kuliah Desain Web Menggunakan Metode Naive Bayes," vol. 2, no. 1, pp. $1-9,2016$.

[9] R. V. Imbar et al., "Implementasi Cosine Similarity dan Algoritma Smith-Waterman untuk Mendeteksi Kemiripan Teks," J. Inform., vol. 10, pp. 31-42, 2014.

[10] D. Darmastuti, "Implementasi Metode Simple Additive Weighting (Saw) Dalam Sistem Informasi Lowongan Kerja Berbasis Web Untuk Rekomendasi Pencari Kerja Terbaik," Program Studi Teknik Informatika Universitas Tanjungpura, Pontianak, 2013. 